\title{
Article \\ Molecular Characteristics and Antioxidant Activity of Spruce (Picea abies) Hemicelluloses Isolated by Catalytic Oxidative Delignification
}

\author{
Valentina S. Borovkova ${ }^{1,2} \mathbb{D}_{\text {, }}$ Yuriy N. Malyar 1,2,*(D), Irina G. Sudakova ${ }^{2}$, Anna I. Chudina ${ }^{2}$, \\ Andrey M. Skripnikov ${ }^{1,2}$, Olga Yu. Fetisova ${ }^{2}$, Alexander S. Kazachenko 1,2 ${ }^{\mathbb{D}}$, Angelina V. Miroshnikova ${ }^{1,2}$, \\ Dmitriy V. Zimonin ${ }^{1,2}$, Vladislav A. Ionin ${ }^{1,2}$, Anastasia A. Seliverstova ${ }^{1}$, Ekaterina D. Samoylova ${ }^{1}$ and \\ Noured dine Issaoui ${ }^{3}$ (D)
}

Citation: Borovkova, V.S.; Malyar, Y.N.; Sudakova, I.G.; Chudina, A.I.; Skripnikov, A.M.; Fetisova, O.Y.; Kazachenko, A.S.; Miroshnikova, A.V.; Zimonin, D.V.; Ionin, V.A.; et al. Molecular Characteristics and Antioxidant Activity of Spruce (Picea abies) Hemicelluloses Isolated by Catalytic Oxidative Delignification. Molecules 2022, 27, 266. https:// doi.org/10.3390/molecules27010266

Academic Editor: Larbi Rhazi

Received: 10 December 2021 Accepted: 30 December 2021 Published: 2 January 2022

Publisher's Note: MDPI stays neutral with regard to jurisdictional claims in published maps and institutional affiliations.

Copyright: (C) 2022 by the authors. Licensee MDPI, Basel, Switzerland. This article is an open access article distributed under the terms and conditions of the Creative Commons Attribution (CC BY) license (https:// creativecommons.org/licenses/by/ $4.0 /)$.
1 School of Non-Ferrous Metals and Materials Science, Siberian Federal University, pr. Svobodny 79, 660041 Krasnoyarsk, Russia; bing0015@mail.ru (V.S.B.); skripnikov@yandex.ru (A.M.S.); leo_lion_leo@mail.ru (A.S.K.); miroshnikova35@gmail.com (A.V.M.); zimonind89@mail.ru (D.V.Z.); s179490@yandex.ru (V.A.I.); aaseliverstova@sfu-kras.ru (A.A.S.); yekaterina.sam09041998@mail.ru (E.D.S.)

2 Krasnoyarsk Science Center, Institute of Chemistry and Chemical Technology, Siberian Branch, Russian Academy of Sciences, Akademgorodok 50/24, 660036 Krasnoyarsk, Russia; sudakova_irina@mail.ru (I.G.S.); bai77@list.ru (A.I.C.); fou1978@mail.ru (O.Y.F.)

3 Laboratory of Quantum and Statistical Physics (LR18ES18), Faculty of Sciences, University of Monastir, Monastir 5079, Tunisia; issaoui_noureddine@yahoo.fr

* Correspondence: yumalyar@gmail.com; Tel.: +79-(08)-2065517

\begin{abstract}
Spruce (Picea abies) wood hemicelluloses have been obtained by the noncatalytic and catalytic oxidative delignification in the acetic acid-water-hydrogen peroxide medium in a processing time of 3-4 $\mathrm{h}$ and temperatures of $90-100{ }^{\circ} \mathrm{C}$. In the catalytic process, the $\mathrm{H}_{2} \mathrm{SO}_{4}, \mathrm{MnSO}_{4}, \mathrm{TiO}_{2}$, and $\left(\mathrm{NH}_{4}\right)_{6} \mathrm{Mo}_{7} \mathrm{O}_{24}$ catalysts have been used. A polysaccharide yield of up to $11.7 \mathrm{wt} \%$ has been found. The hemicellulose composition and structure have been studied by a complex of physicochemical methods, including gas and gel permeation chromatography, Fourier-transform infrared spectroscopy, and thermogravimetric analysis. The galactose:mannose:glucose:arabinose:xylose monomeric units in a ratio of 5:3:2:1:1 have been identified in the hemicelluloses by gas chromatography. Using gel permeation chromatography, the weight average molar mass $\mathrm{M}_{\mathrm{w}}$ of hemicelluloses has been found to attain $47,654 \mathrm{~g} / \mathrm{mol}$ in noncatalytic delignification and up to $42,793 \mathrm{~g} / \mathrm{mol}$ in catalytic delignification. Based on the same technique, a method for determining the $\alpha$ and $k$ parameters of the Mark-Kuhn-Houwink equation for hemicelluloses has been developed; it has been established that these parameters change between $0.33-1.01$ and 1.57-472.17, respectively, depending on the catalyst concentration and process temperature and time. Moreover, the FTIR spectra of the hemicellulose samples contain all the bands characteristic of heteropolysaccharides, specifically, $1069 \mathrm{~cm}^{-1}(\mathrm{C}-\mathrm{O}-\mathrm{C}$ and $\mathrm{C}-\mathrm{O}-\mathrm{H}), 1738 \mathrm{~cm}^{-1}$ (ester $\left.\mathrm{C}=\mathrm{O}\right), 1375 \mathrm{~cm}^{-1}\left(-\mathrm{C}-\mathrm{CH}_{3}\right), 1243 \mathrm{~cm}^{-1}$ (-C-O-), etc. It has been determined by the thermogravimetric analysis that the hemicelluloses isolated from spruce wood are resistant to heating to temperatures of up to $\sim 100{ }^{\circ} \mathrm{C}$ and, upon further heating, start destructing at an increasing rate. The antioxidant activity of the hemicelluloses has been examined using the compounds simulating the 2,2-diphenyl-2-picrylhydrazyl free radicals.
\end{abstract}

Keywords: wood polysaccharides; delignification; hemicellulose; antioxidant activity; molecular weight distribution; gel permeation chromatography

\section{Introduction}

Hemicelluloses (HCs) are plant cell wall polysaccharides, which are the second most widely used renewable plant polymers after cellulose in lignocellulosic materials. They represent heteropolysaccharides with a disordered polymer structure consisting of different sugar units [1], depending on a plant type and extraction method. The HCs that are 
dominant in softwood are partially acetylated galactoglucomannans and glucomannans (up to $20-25 \%$ of the wood weight) and arabinoglucuronoxylans (7-10\% of the wood weight) $[2,3]$.

Wood HCs are an abundant, but still unused by-products of the pulp and paper and hydrolysis industries. However, the early investigations charted the trends in using HCs in different production areas.

According to the literature data on the isolation and application of $\mathrm{HCs}$, these natural polymers can be used in biomedicine owing to their nontoxicity, biocompatibility, and biodegradability $[4,5]$. It was proposed to employ HCs in packaging films [6] and 3D printing [7]. Deloule et al. [5], Gautam et al. [8], and Mikkonen et al. [9] demonstrated the wide possibilities of using the HCs extracted from conifers as prebiotics, adsorbents, and stabilizers of alkyd paints.

In the recent works devoted to the extraction of HCs from wood raw materials, methods for the HC isolation via the hot water extraction $[10,11]$, pretreatment with hot water under pressure [12], alkaline treatment with hydrogen peroxide [13], etc. [14-16] were proposed. At present, new methods for HC production are being developed, which are based on using organic solvents, for example, carboxylic acids, as a delignification medium for wood processing. Among these promising methods is oxidative delignification in acetic acid-water-hydrogen peroxide medium in the presence of different catalysts [17-19]. The pretreatment using acetic acid with hydrogen peroxide allows the efficient fractionation of lignocellulosic materials and cleavage of the lignin aromatic rings at the preserved polymer structure of other carbohydrates [20,21]. Importantly, the delignification products consisting of soluble HCs and lignin depolymerization products are free of toxic chlorine and sulfur-containing compounds [1,22]. In addition, the presence of various catalysts, especially those based on variable valence metals, intensifies the delignification process due to the formation of peroxocomplexes, which are strong oxidants and destruct lignin more completely $[23,24]$.

Norway spruce (Picea abies) is an evergreen coniferous widespread in most of Europe. Numerous studies showed that the components of the spruce wood and needles exhibit wide-range biological activities, including antioxidant [25], immunomodulatory [26], anticancer [27], anti-inflammatory, antifungal, and others [28,29].

This work is aimed at the extraction of HCs from Picea abies wood by oxidative delignification in acetic acid-water-hydrogen peroxide medium with the $(\mathrm{NH} 4)_{6} \mathrm{Mo}_{7} \mathrm{O}_{24}, \mathrm{MnSO}_{4}$, $\mathrm{TiO}_{2}$, and $\mathrm{H}_{2} \mathrm{SO}_{4}$ catalysts and without them; gel permeation chromatography (GPC) examination of the dependence of the HC molar mass on the delignification conditions; gas chromatography (GC) investigations of the HC monosaccharide composition; analysis of the structural changes and thermal stability of the obtained samples by Fourier-transform infrared (FTIR) spectroscopy and thermogravimetric analysis (TGA); and study of the bioactivity of the HCs using the compound modeling free and hydroxyl radicals for determining their characteristics in terms of future application.

\section{Results and Discussion}

\subsection{Delignification and Yield of the Hemicelluloses}

The HCs of spruce wood were extracted from liquid products of oxidative delignification in the hydrogen peroxide-acetic acid-water medium after isolation of cellulose. The delignification conditions were chosen based on study [17], where it was shown that, at process temperatures of $90-100{ }^{\circ} \mathrm{C}$, process times of 3-4 h, a hydrogen peroxide content of $6 \mathrm{wt} \%$, an acetic acid content of $30 \mathrm{wt} \%$, and a liquid/wood ratio (LWR) of 15, the deepest delignification of wood occurs, which ensures a residual lignin content below 1\% in the cellulosic product. The dissolved HCs were isolated from the liquid delignification products by ethanol precipitation.

The yields of HCs extracted from the products of the oxidative catalytic and noncatalytic delignification of spruce wood in the hydrogen peroxide-acetic acid-water medium are given in Table 1. 
Table 1. Hemicellulose yields from the soluble products of oxidative delignification of spruce wood with and without catalysts at process temperatures of $90^{\circ} \mathrm{C}$ and $100{ }^{\circ} \mathrm{C}$ and process times of 3 and $4 \mathrm{~h}$.

\begin{tabular}{|c|c|c|c|c|}
\hline \multirow{3}{*}{ Samples ${ }^{1}$} & \multicolumn{4}{|c|}{ Hemicellulose Yield (wt $\%)^{2}$} \\
\hline & \multicolumn{2}{|c|}{$90\left({ }^{\circ} \mathrm{C}\right)$} & \multicolumn{2}{|c|}{$100\left({ }^{\circ} \mathrm{C}\right)$} \\
\hline & 3 (h) & 4 (h) & 3 (h) & $4(\mathrm{~h})$ \\
\hline $\mathrm{HC}_{\text {no cat }}{ }^{3}$ & 8.6 & 10.1 & 10.4 & 11.7 \\
\hline $\mathrm{HC}_{\mathrm{Mo}} 4$ & 7.9 & 9.2 & 10.1 & 10.9 \\
\hline $\mathrm{HC}_{\mathrm{Mn}} 5$ & 5.9 & 8.2 & 10.7 & 9.05 \\
\hline $\mathrm{HC}_{\mathrm{Ti}}{ }^{6}$ & 5.8 & 8.0 & 8.4 & 7.0 \\
\hline $\mathrm{HC}_{\mathrm{H}_{2} \mathrm{SO}_{4}}{ }^{7}$ & 0.9 & 1.1 & 2.3 & 1.5 \\
\hline
\end{tabular}

${ }^{1}$ The ratio between the delignifying solution components $\mathrm{CH}_{3} \mathrm{COOH}: \mathrm{H}_{2} \mathrm{O}_{2}: \mathrm{H}_{2} \mathrm{O}$ is 6:30:15; the amount of catalyst is $1 \mathrm{wt} \%$ of the wood weight; ${ }^{2}$ Relative to the initial air-dry spruce wood; ${ }^{3}$ The hemicelluloses obtained by noncatalytic delignification; ${ }^{4}$ The hemicelluloses obtained in the presence of the $\left(\mathrm{NH}_{4}\right)_{6} \mathrm{Mo}_{7} \mathrm{O}_{24}$ catalyst; ${ }^{5}$ The hemicelluloses obtained in the presence of the $\mathrm{MnSO}_{4}$ catalyst; ${ }^{6}$ The hemicelluloses obtained in the presence of the $\mathrm{TiO}_{2}$ catalyst; ${ }^{7}$ The hemicelluloses obtained in the presence of the $\mathrm{H}_{2} \mathrm{SO}_{4}$ catalyst.

According to the data given in Table 1, the HC yield at a process temperature of $90{ }^{\circ} \mathrm{C}$ is mainly lower than that obtained at $100{ }^{\circ} \mathrm{C}$. This is due to the fact that, at $100{ }^{\circ} \mathrm{C}$, wood delignification is probably completed.

The use of the $\left(\mathrm{NH}_{4}\right)_{6} \mathrm{Mo}_{7} \mathrm{O}_{24}$ and $\mathrm{MnSO}_{4}$ catalysts ensures a fairly high $\mathrm{HC}$ yield at $90{ }^{\circ} \mathrm{C}$, while the $\mathrm{HC}$ yield obtained with the $\mathrm{MnSO}_{4}$ catalyst at $100{ }^{\circ} \mathrm{C}$ for $4 \mathrm{~h}$ decreases. The $\mathrm{TiO}_{2}$ catalyst works much more efficiently at process parameters of $100{ }^{\circ} \mathrm{C}$ and $3 \mathrm{~h}$ than at $100{ }^{\circ} \mathrm{C}$ and $4 \mathrm{~h}$. When the $\mathrm{H}_{2} \mathrm{SO}_{4}$ catalyst is used, the $\mathrm{HC}$ yield is the lowest, which is apparently related to the strong destructive effect of this catalyst on polysaccharides.

\subsection{Monosaccharide Composition of the Hemicelluloses}

The carbohydrate composition of the HCs obtained by the oxidative catalytic and noncatalytic delignification of spruce wood is shown in Figure 1. The HC monosaccharide composition revealed the presence of large amounts of mannose, galactose, and glucose and minor amounts of arabinose and xylose in a ratio of 5:3:2:1:1. The highest galactose and mannose contents in the HC composition point out that the dominant polysaccharide in the obtained HCs is galactoglucomannan. The presence of small amounts of xylose and arabinose is indicative of the presence of another important polysaccharide: arabinoglucuronoxylan. These components determined for the spruce (Picea abies) HCs are analogous to those reported in the previous studies on the $\mathrm{HC}$ isolation from coniferous, although their ratios are somewhat different $[1,13]$.

\subsection{Gel Permeation Chromatography Study of the Hemicelluloses}

The determination of the conformational and molecular mass characteristics of the HCs obtained by oxidative delignification can open up new prospects for studying the interplay between the structure and properties of polysaccharides, which will make it possible to obtain HCs with controlled characteristics for further use in pharmacology, the food industry, etc. The information about the structure of the polysaccharide chain in an aqueous solution can be obtained by comparing molar masses with some hydrodynamic parameters, e.g., the intrinsic viscosity. This dependence is described by the Mark-Houwink-Sakurada (MHS) equation $[\eta]=\mathrm{KM}^{\alpha}$. In the logarithmic coordinates, $\alpha$ is the slope of a straight, which characterizes the conformation of molecules in a solvent. The coefficient $\alpha$ is $\sim 0.0$ for hard spheres, $\sim 0.5$ for linear random coils in theta solvents (e.g., DMSO), 0.5-0.8 for linear polymers in thermodynamically good solvents, and 1.8-2.0 for rigid rods. The change in the coefficient $\mathrm{K}$ at the constant $\alpha$ values allows one to judge the branching of polymer molecules. A slope of $\sim 0.58$ is typical of linear polymers in thermodynamically good solvents, while its lower values are indicative of branching (0.33 for compact spheres) [30]. 


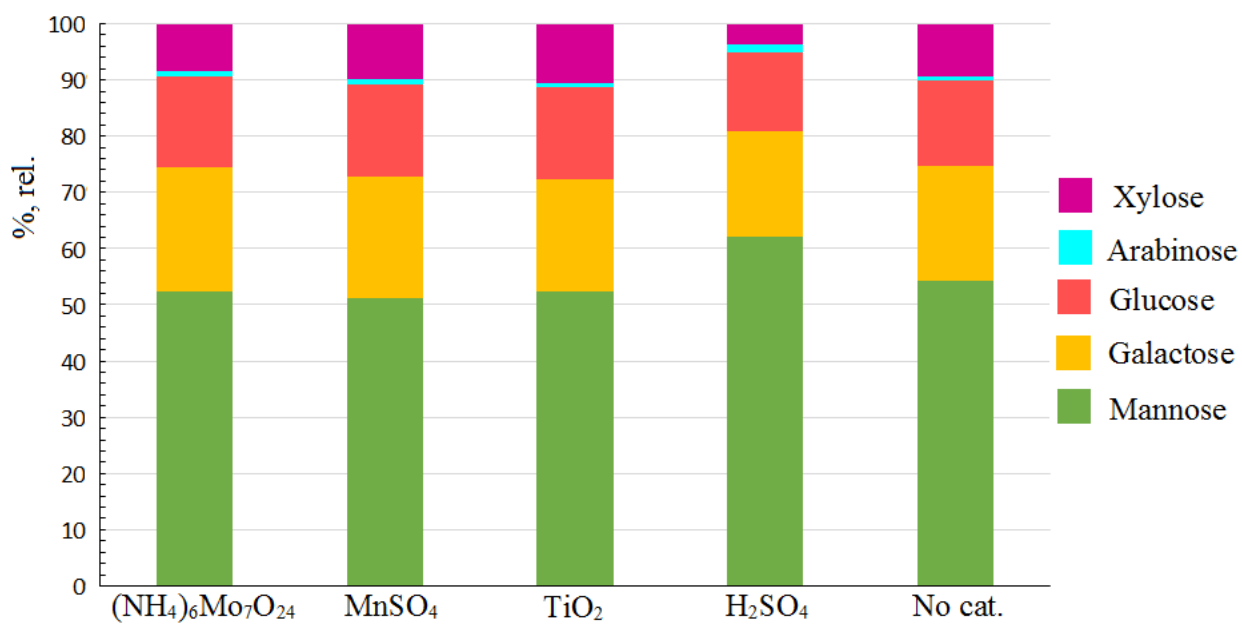

Figure 1. Monosaccharide composition of the hemicelluloses isolated from liquid products of oxidative delignification of spruce wood with different catalysts and without them (percentage of the total monosaccharide content).

The molecular weight distribution (MWD) curves and MHS plots for the HCs obtained by oxidative delignification of spruce wood are presented in Figure 2 and the corresponding data are given in Table 2.

According to the molecular weight distributions, all the $\mathrm{HC}$ samples are homogeneous with a slight polydispersity (1.8-3.3).

When the $\left(\mathrm{NH}_{4}\right)_{6} \mathrm{Mo}_{7} \mathrm{O}_{24}$ catalyst is used at process parameters of $90{ }^{\circ} \mathrm{C}$ and $4 \mathrm{~h}$, the obtained HC sample has a polydispersity index (PDI) of 3.354, which is explained by the presence of low molar mass fractions. The coefficient $\alpha=0.45$ suggests that the polysaccharide has a form of a linear random coil. As the process temperature increases to $100{ }^{\circ} \mathrm{C}$, first (for $3 \mathrm{~h}$ ) the $\mathrm{HC}$ molar mass slightly increase, the $\alpha$ coefficient grows to 0.63 , and the MHS curve shifts (Figure 2a). This is indicative of a change in the HC conformation and the increased branching of the polymer, which is probably related to the partial oxidation of hydroxyl groups to carboxyl ones. With an increase in the processing time, partial hydrolysis of the side chains occurs, which can be concluded from the shift of the molecular weight distribution curve to the low molar mass region and an increase in the coefficient $\mathrm{K}$ (the weakened branching of polymer chains).

Table 2. Molar mass characteristics of the spruce wood hemicelluloses.

\begin{tabular}{|c|c|c|c|c|c|c|c|}
\hline HC Sample & Catalyst & $\mathrm{T}\left({ }^{\circ} \mathrm{C}\right)$ & $t(h)$ & $M_{w}(g / m o l)$ & PDI & $\mathbf{K}$ & $\alpha$ \\
\hline $\mathrm{HC}_{\mathrm{Mo}} 90-4$ & $\left(\mathrm{NH}_{4}\right)_{6} \mathrm{Mo}_{7} \mathrm{O}_{24}$ & 90 & 4 & 17,367 & 3.354 & 442.43 & 0.45 \\
\hline $\mathrm{HC}_{\mathrm{Mo}} 100-3$ & $\left(\mathrm{NH}_{4}\right)_{6} \mathrm{Mo}_{7} \mathrm{O}_{24}$ & 100 & 3 & 16,797 & 1.883 & 37.48 & 0.63 \\
\hline $\mathrm{HC}_{\mathrm{Mo}} 100-4$ & $\left(\mathrm{NH}_{4}\right)_{6} \mathrm{Mo}_{7} \mathrm{O}_{24}$ & 100 & 4 & 12,471 & 2.11 & 69.17 & 0.63 \\
\hline $\mathrm{HC}_{\mathrm{Mn}} 90-4$ & $\mathrm{MnSO}_{4}$ & 90 & 4 & 18,963 & 2.022 & 56.36 & 0.61 \\
\hline $\mathrm{HC}_{\mathrm{Mn}} 100-3$ & $\mathrm{MnSO}_{4}$ & 100 & 3 & 20,382 & 2.053 & 64.85 & 0.58 \\
\hline $\mathrm{HC}_{\mathrm{Mn}} 100-4$ & $\mathrm{MnSO}_{4}$ & 100 & 4 & 19,061 & 2.198 & 272.03 & 0.42 \\
\hline $\mathrm{HC}_{\mathrm{Ti}} 90-4$ & $\mathrm{TiO}_{2}$ & 90 & 4 & 42,793 & 3.255 & 472.17 & 0.33 \\
\hline $\mathrm{HC}_{\mathrm{Ti}} 100-3$ & $\mathrm{TiO}_{2}$ & 100 & 3 & 29,962 & 2.612 & 128.00 & 0.46 \\
\hline $\mathrm{HC}_{\mathrm{Ti}} 100-4$ & $\mathrm{TiO}_{2}$ & 100 & 4 & 35,363 & 2.646 & 273.17 & 0.35 \\
\hline $\mathrm{HC}_{\text {no cat }} 90-4$ & w/o cat & 90 & 4 & 47,645 & 2.145 & 25.41 & 0.59 \\
\hline $\mathrm{HC}_{\text {no cat }} 100-4$ & $\mathrm{w} / \mathrm{o}$ cat & 100 & 4 & 40,885 & 2.917 & 148.32 & 0.41 \\
\hline $\mathrm{HC}_{\mathrm{H}_{2} \mathrm{SO}_{4}} 100-4$ & $\mathrm{H}_{2} \mathrm{SO}_{4}$ & 100 & 2 & 12,845 & 1.815 & 1.57 & 1.01 \\
\hline
\end{tabular}




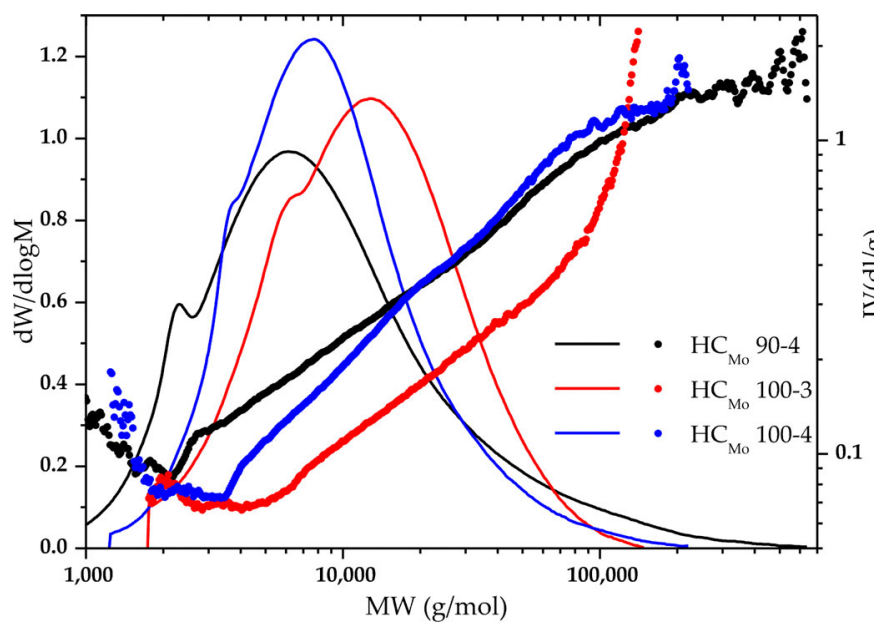

(a)

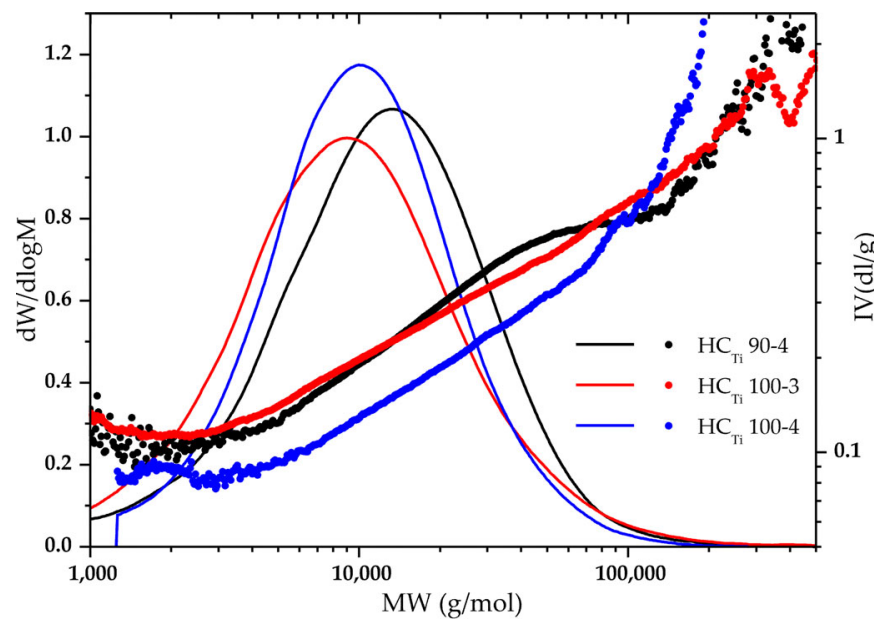

(c)

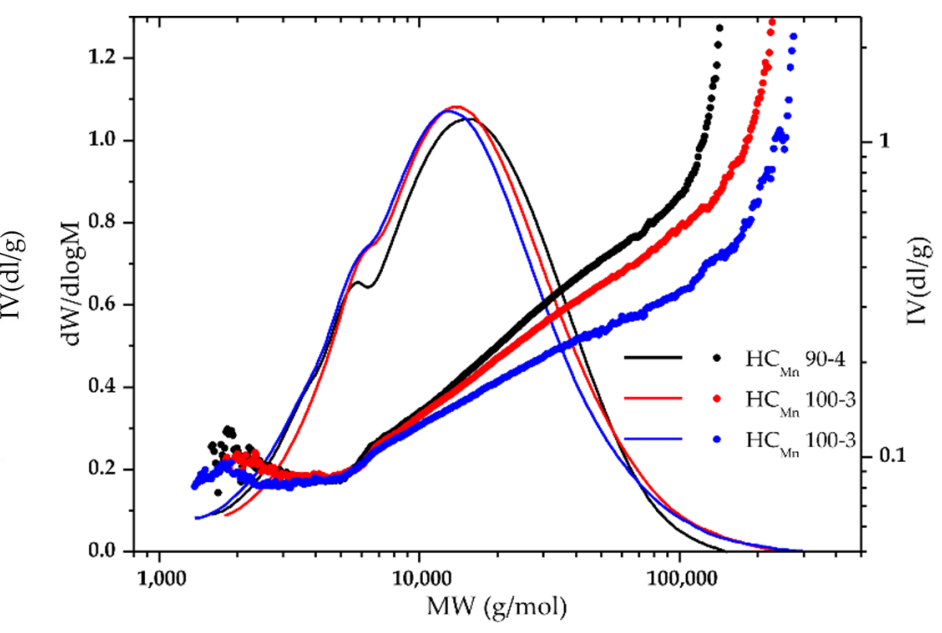

(b)

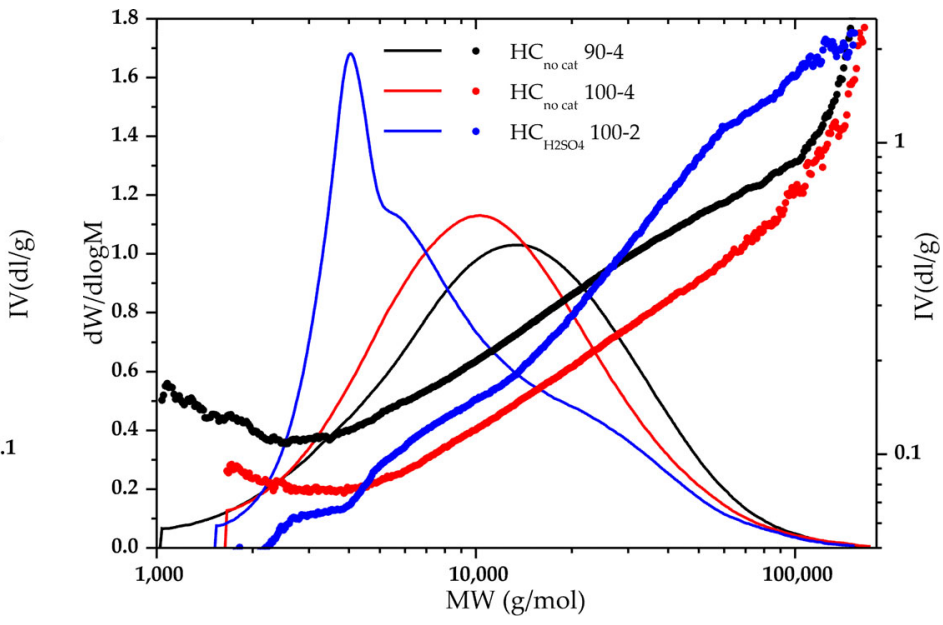

(d)

Figure 2. Molecular weight distribution curves and Mark-Houwink-Sakurada plots for the hemicelluloses obtained by oxidative delignification of spruce wood with the (a) $\left(\mathrm{NH}_{4}\right)_{6} \mathrm{Mo}_{7} \mathrm{O}_{24},(\mathbf{b}) \mathrm{MnSO}_{4}$, (c) $\mathrm{TiO}_{2}$, and (d) $\mathrm{H}_{2} \mathrm{SO}_{4}$ catalysts and without them.

The HCs isolated in the presence of $\mathrm{MnSO}_{4}$ under varying conditions are fairly homogeneous: the MWD curves (Figure $2 \mathrm{~b}$ ) are almost identical, $\mathrm{M}_{\mathrm{w}} \sim 19 \mathrm{~kg} / \mathrm{mol}$, and $\mathrm{PD} \sim 2$. The main change is observed in the slope of the MHS curve (from 0.61 to 0.42 ), which can be attributed to the change in the polysaccharide chain conformation from the linear structure to a coil.

When $\mathrm{TiO}_{2}$ is used as a catalyst in oxidative delignification at $90{ }^{\circ} \mathrm{C}$ for $4 \mathrm{~h}$, the obtained HC sample has a high polydispersity index (3.255) and a fairly high molar mass $\left(\mathrm{M}_{\mathrm{W}} \sim 43 \mathrm{~kg} / \mathrm{mol}\right)$. An increase in the process temperature to $100{ }^{\circ} \mathrm{C}$ leads to a shift of the MWD curve to the low molar mass region $\left(\mathrm{M}_{\mathrm{w}} \sim 30 \mathrm{~kg} / \mathrm{mol}\right.$ ) (Figure 2c). An increase in the process time significantly affects the polymer branching: the MHS curve shifts. This is, most likely, due to the partial oxidation of the HC hydroxyl groups, which leads to an increase in the polymer molar mass $\left(\mathrm{M}_{\mathrm{w}} \sim 35 \mathrm{~kg} / \mathrm{mol}\right)$ and in branching.

The HC samples obtained at a temperature of $90{ }^{\circ} \mathrm{C}$ for a process time of $4 \mathrm{~h}$ without a catalyst have a high molar mass $\left(\mathrm{M}_{\mathrm{w}} \sim 47 \mathrm{~kg} / \mathrm{mol}\right.$ ) (Figure 2d). This may be due to the mild conditions for the polysaccharide isolation when the depolymerization processes almost do not occur. However, the temperature growth intensifies the depolymerization processes, which is reflected in a decrease in the molar mass to $\mathrm{M}_{\mathrm{w}} \sim 40 \mathrm{~kg} / \mathrm{mol}$. In this case, hydroxyl 
groups are partially oxidized, probably on the surface of a polysaccharide coil. This process is confirmed by a shift of the MHS curve and a decrease in the coefficient $\alpha$ to 0.41 .

The presence of sulfuric acid as a catalyst in the reaction mixture does not allow one to obtain a significant HC yield. For instance, the product obtained at a temperature of $100{ }^{\circ} \mathrm{C}$ for $2 \mathrm{~h}$ has a low molar mass $\left(\mathrm{M}_{\mathrm{W}} \sim 12 \mathrm{~kg} / \mathrm{mol}\right)$. Analysis of the MWD curve profile (Figure $2 \mathrm{~d}$ ) reveals a small high molar mass region corresponding to the native $\mathrm{HC}$ and two peaks with $\mathrm{M}_{\mathrm{w}} \sim 4$ and $\sim 6 \mathrm{~kg} / \mathrm{mol}$ corresponding to the oligomeric products of $\mathrm{HC}$ hydrolysis, which is indicative of the inhomogeneous product composition.

\subsection{Fourier-Transform Infra-Red Spectroscopy Study of the Hemicelluloses}

The infra-red (IR) spectra of the HC samples include all the bands typical of heteropolysaccharides (Figure 3). Specifically, the characteristic high-intensity band of a hydroxyl group is observed around $\sim 3423 \mathrm{~cm}^{-1}$, which points out strong intra- and intermolecular interactions between the polysaccharide chains [27].

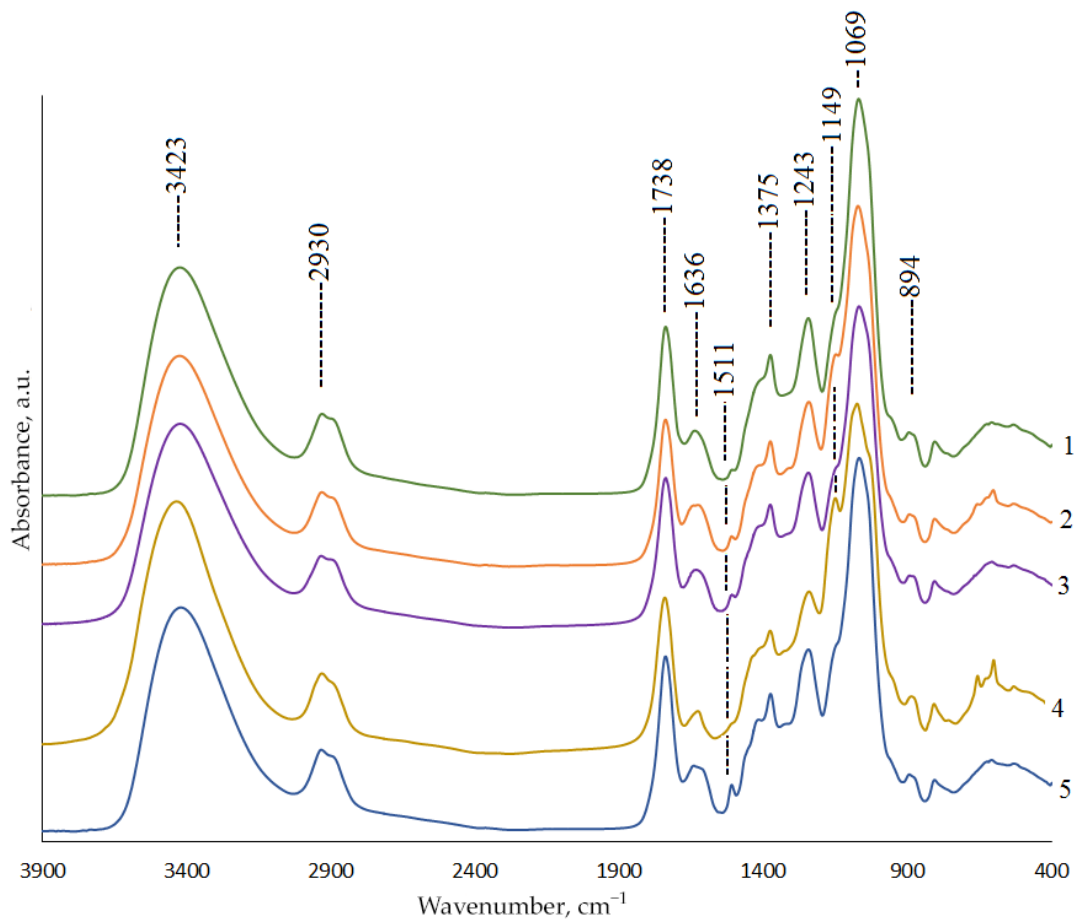

Figure 3. IR spectra of the hemicelluloses obtained by the oxidative delignification of spruce wood with (1) the $\left(\mathrm{NH}_{4}\right)_{6} \mathrm{Mo}_{7} \mathrm{O}_{24},(2) \mathrm{MnSO}_{4}$, (3) $\mathrm{TiO}_{2}$, and (4) $\mathrm{H}_{2} \mathrm{SO}_{4}$ catalysts and (5) without them.

The band around $2930 \mathrm{~cm}^{-1}$ was attributed to the $\mathrm{C}-\mathrm{H}$ stretching vibration. The intense absorption band at $1069 \mathrm{~cm}^{-1}$ was attributed to the $\mathrm{C}-\mathrm{O}-\mathrm{C}$ and $\mathrm{C}-\mathrm{O}-\mathrm{H}$ stretching vibrations of a pyranose ring [1,27]. In addition, all the $\mathrm{HC}$ samples are acetylated, which is reflected in three acetyl ether bands at $1738 \mathrm{~cm}^{-1}$ (ester $\left.\mathrm{C}=\mathrm{O}\right), 1375 \mathrm{~cm}^{-1}\left(-\mathrm{C}-\mathrm{CH}_{3}\right)$, and $1243 \mathrm{~cm}^{-1}$ (-C-O-). Furthermore, the characteristic absorption around $894 \mathrm{~cm}^{-1}$ corresponds to the typical signal of the $\beta$ configuration in polysaccharides. The residual lignin absorption band at $1511 \mathrm{~cm}^{-1}$ is most pronounced in the spectrum of the HCs obtained without a catalyst, which evidences incomplete delignification. When the $\left(\mathrm{NH}_{4}\right)_{6} \mathrm{Mo}_{7} \mathrm{O}_{24}$, $\mathrm{MnSO}_{4}$, and $\mathrm{TiO}_{2}$ catalysts are used, this band is insignificant [1]; in the case of the $\mathrm{H}_{2} \mathrm{SO}_{4}$ catalyst used, it is completely absent. -

\subsection{Thermogravimetric Analysis of the Hemicelluloses}

The thermal properties of the HC samples were studied by the TGA. Figure $4 a, b$ presents the derivative thermogravimetric (DTG) and thermogravimetric (TG) curves for the HC samples. 


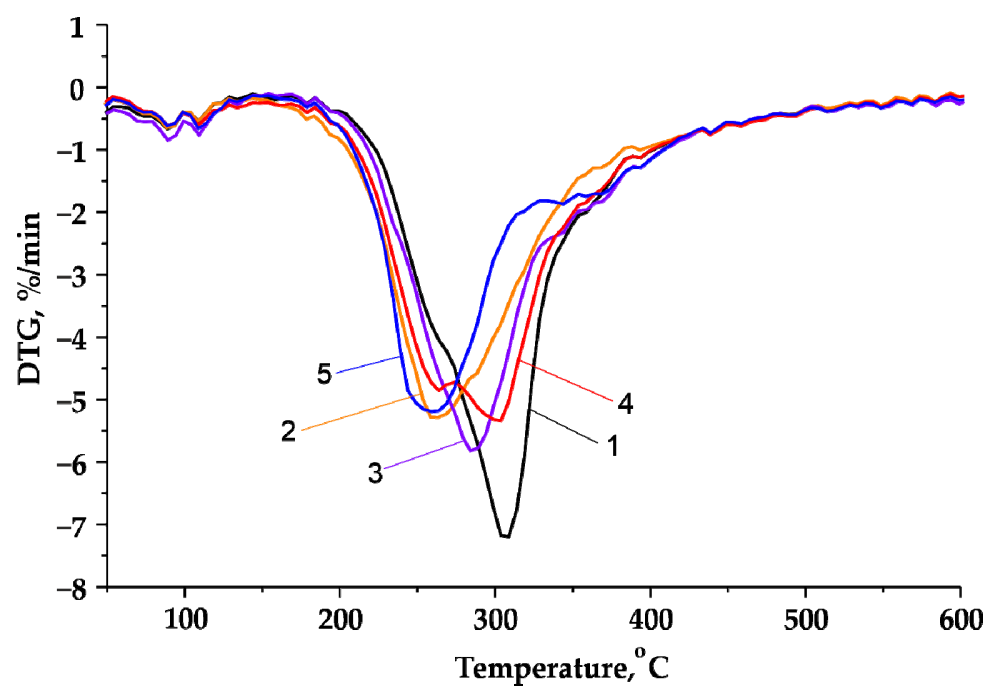

(a)

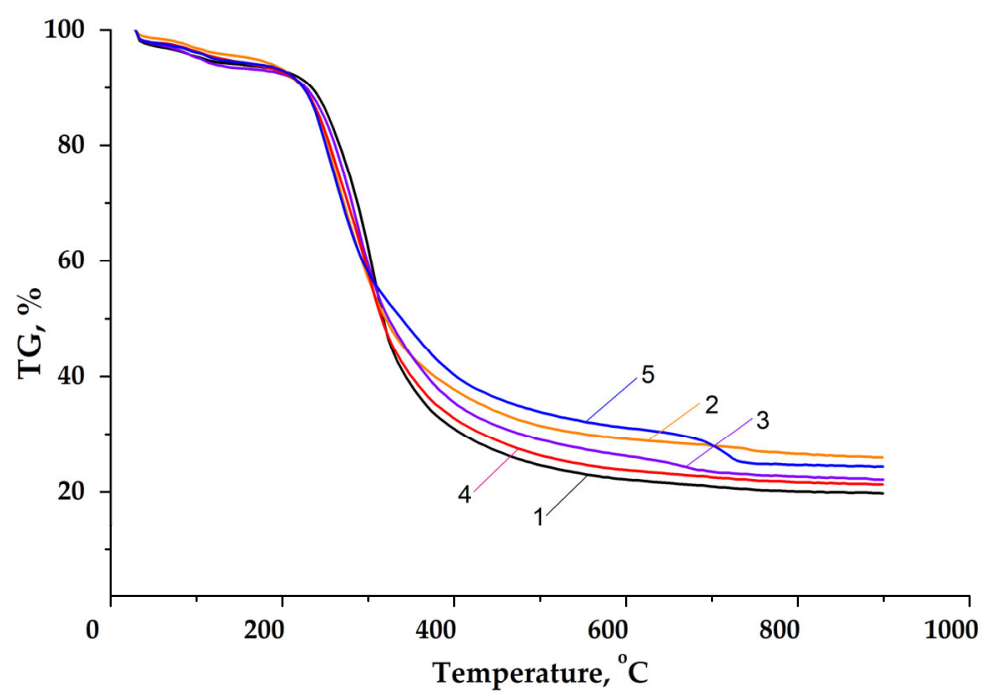

(b)

Figure 4. (a) DTG and (b) TG curves for the hemicelluloses extracted from the liquid products of the catalytic and noncatalytic delignification of spruce wood: (1) $\mathrm{HC}_{\mathrm{w} / \mathrm{o} \text { cat }}$ (2) $\mathrm{HC}_{\mathrm{Mo}}$, (3) $\mathrm{HC}_{\mathrm{Mn}}$, (4) $\mathrm{HC}_{\mathrm{Ti}}$, and (5) $\mathrm{HC}_{\mathrm{H}_{2} \mathrm{SO}_{4}}$.

The HCs isolated from spruce wood are resistant to heating to temperatures of up to $\sim 100{ }^{\circ} \mathrm{C}$ and, upon further heating, start destructing at an increasing rate, as was shown by us in $[1,31]$. The thermal decomposition of the HC samples can be divided into three stages. At the first stage, the weight loss observed at temperatures of up to $100{ }^{\circ} \mathrm{C}$ is caused by the evaporation of adsorbed water. At the second stage, at relatively low (up to $200{ }^{\circ} \mathrm{C}$ ) temperatures, the hydrolysis of ester groups apparently dominates and, due to the formation of acetic acid, the reactions of hydrolytic destruction of polysaccharides occur; further, the HCs are intensively decomposed, which begins at $\sim 250{ }^{\circ} \mathrm{C}$ in all the samples.

As the temperature increases above $250{ }^{\circ} \mathrm{C}$, the thermal destruction reactions with the hemolytic opening of the glycosidic and $\mathrm{C}-\mathrm{C}$ bonds in the monosaccharide links already occur. In the investigated HC samples, the most rapid weight loss was observed at 270$320{ }^{\circ} \mathrm{C}$. The intense decomposition ends at a temperature of $\sim 340{ }^{\circ} \mathrm{C}$ for the four samples and at $300{ }^{\circ} \mathrm{C}$ for the sample obtained with the $\mathrm{H}_{2} \mathrm{SO}_{4}$ catalyst. 


\subsection{Elemental Analysis of the Hemicelluloses}

The elemental composition of the HCs isolated from the liquid products of the catalytic and noncatalytic delignification of spruce wood in the acetic acid-hydrogen peroxide-water medium is given in Table 3 .

Table 3. Carbon, hydrogen, and oxygen contents in the hemicellulose samples.

\begin{tabular}{cccc}
\hline Sample & $\mathbf{C ~ ( \% )}$ & $\mathbf{H ~ ( \% )}$ & $\mathbf{O}^{\mathbf{1}} \mathbf{( \% )}$ \\
\hline $\mathrm{HC}_{\mathrm{Mo}}$ & 40.96 & 5.96 & 53.08 \\
$\mathrm{HC}$ & 39.74 & 5.92 & 54.34 \\
$\mathrm{HC}$ & 42.10 & 6.08 & 51.82 \\
$\mathrm{HC}_{\mathrm{Ti}_{2} \mathrm{SO}_{4}}$ & 36.44 & 5.77 & 57.78 \\
$\mathrm{HC}_{\text {no cat }}$ & 42.85 & 6.14 & 51.01 \\
\hline
\end{tabular}

${ }^{1}$ Calculated as a difference $100 \%-\mathrm{C}(\%)-\mathrm{H}(\%)$.

The elemental analysis revealed an increase in the oxygen fraction in the $\mathrm{HC}_{\mathrm{Mo}}$ sample, which may be indicative of the presence of oxidized forms (uronic acids) in the structure. In the $\mathrm{HC}_{\mathrm{Mn}}$ sample, the percentage of oxygen is higher than in the other samples: it approaches the values calculated for polyuronic acids. The increased number of carboxyl groups is consistent with the obtained data on antioxidant activity.

The elemental composition of the $\mathrm{HC}_{\mathrm{Ti}}$ sample is similar to that of the sample obtained by the noncatalytic delignification; however, in the presence of the $\mathrm{TiO}_{2}$ catalyst, the $\mathrm{HC}$ partially oxidizes with the preserved native polymer structure, which is consistent with the GPC and FTIR data.

The maximum percentage of oxygen was found in the sample obtained using sulfuric acid, which is explained by the break of glycosidic bonds and further oxidation of the end groups.

\subsection{Antioxidant Activity of the Hemicelluloses}

A method widely used for determining the antioxidant activity is the 2,2-diphenyl-1picrylhydrazyl (DPPH) free radical scavenging [32]. The stable nitrogen-centered lipophilic free radical DPPH exhibits the characteristic absorption at $517 \mathrm{~nm}$ and has a purple color in primary alcohols (methanol, ethanol and others) [32-35]. At the reduction by antioxidants to the nonradical DPPH-H form, the purple color rapidly disappears. The absorption capacities of the HCs were determined using the DPPH radical; the results are shown in Figure 5 in comparison with the Vitamin $\mathrm{C}(\mathrm{Vc})$ used for a positive control [32].

It is well-known that the specific functional groups, e.g., sulfate, amino, hydroxyl, and carboxyl ones, can be related to the antioxidative effect of polysaccharides [36]. It was found that all the HC samples have the lower activity with respect to DPPH as compared with Vc. All the HCs extracted with the catalysts showed the weakest scavenging effect at $0.08 \mathrm{mg} / \mathrm{mL}$ in the range of $0.29 \%$ for $\mathrm{HC}_{\mathrm{H}_{2} \mathrm{SO}_{4}}$ to $13.66 \%$ for $\mathrm{HC}_{\mathrm{Mn}}$. It is noteworthy that $\mathrm{HC}_{\mathrm{Mn}}$ exhibited the strongest scavenging activity, but $\mathrm{HC}_{\mathrm{H} 2 \mathrm{SO} 4}$ had the weakest scavenging activity over the entire range of $0.08-2.0 \mathrm{mg} / \mathrm{mL}$. This is due to the fact that the contents of carboxyl and methoxyl groups of uronic acids, as well as the high content of hydroxyl groups positively affect the antioxidant activity of polysaccharides [36-38]. In addition, it was reported [39] that the galactose-rich polysaccharides have a relatively high antioxidant activity, which is consistent with our data on the monosaccharide composition. The comparable effect on the antioxidant activity is made by the polysaccharides contained in the HCs. The dependence of the antioxidant activity on the percentage of arabinoxylan, galactomannan, and galactoglucomannan in the HC structure was noticed in different studies [40-42]. 


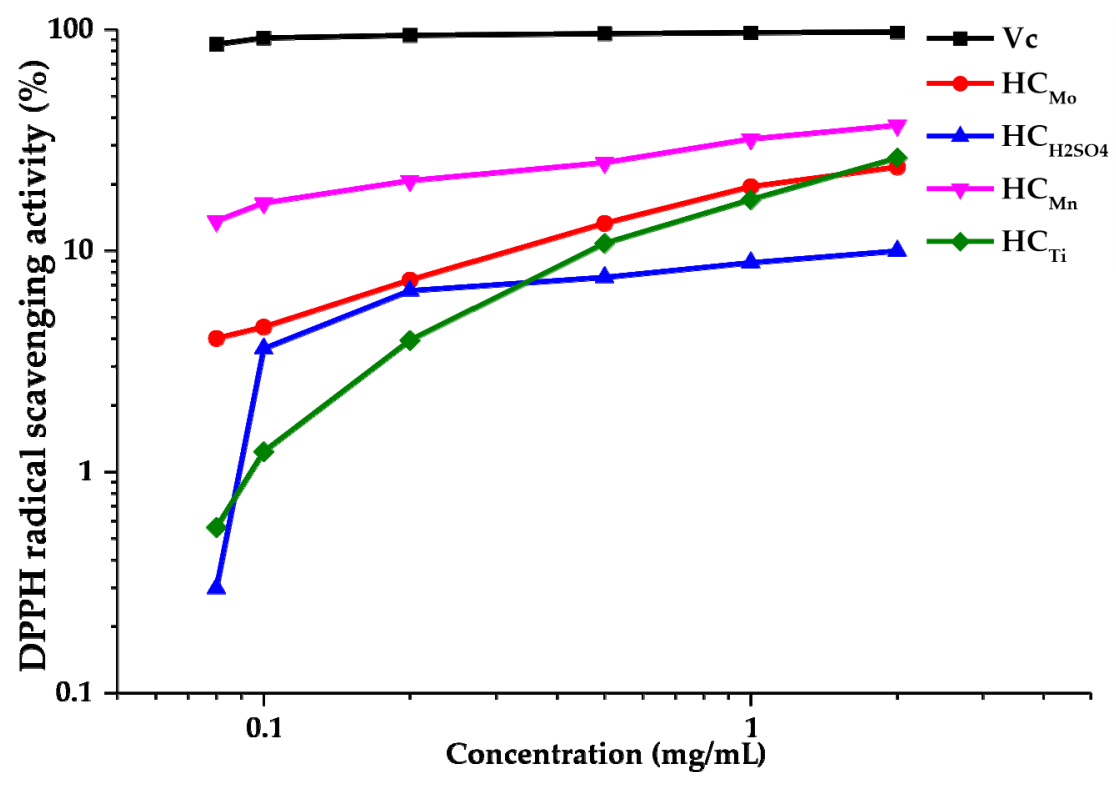

Figure 5. The activity of $\mathrm{Vc}$ and $\mathrm{HC}_{\mathrm{Mo}}, \mathrm{HC}_{\mathrm{Mn}}, \mathrm{HC}_{\mathrm{Ti}}$, and $\mathrm{HC}_{\mathrm{H}_{2} \mathrm{SO}_{4}}$ at different concentrations relative to the DPPH radicals.

\section{Materials and Methods}

\subsection{Materials}

The raw material used was sawdust (a fraction of $2.0-5.0 \mathrm{~mm}$ ) of spruce (Picea abies) grown in the Krasnoyarsk Territory. The sawdust chemical composition was determined using conventional wood chemistry analytical methods [43]. The main spruce wood components were cellulose $(44.4 \mathrm{wt} \%)$, lignin $(30.6 \mathrm{wt} \%)$, hemicelluloses $(22.6 \mathrm{wt} \%)$, extractive substances $(1.8 w \mathrm{t} \%)$, and ash $(0.6 \mathrm{wt} \%)$.

\subsection{Spruce Wood Delignification and Extraction of the Hemicelluloses}

Figure 6 shows a scheme of the catalytic oxidative fractionation of spruce wood in the hydrogen peroxide-acetic acid-water medium with the formation of cellulose, hemicelluloses, and lignin products.

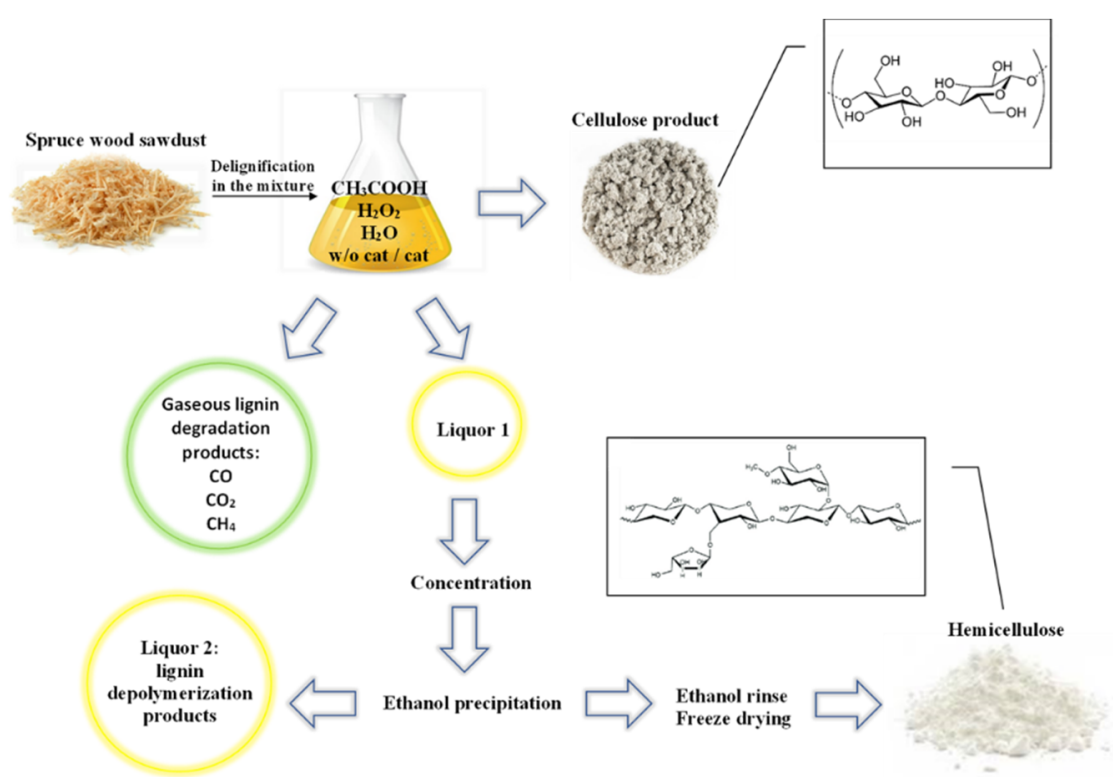

Figure 6. Scheme of the oxidative catalytic fractionation of spruce wood in the hydrogen peroxideacetic acid-water medium with the formation of cellulose, hemicelluloses, and lignin products. 
The shredded spruce wood was delignified in a $250-\mathrm{mL}$ glass reactor equipped with a stirrer and a reflux condenser. The delignification solution consisted of glacial acetic acid $(30 \mathrm{wt} \%)$, hydrogen peroxide $(6 \mathrm{wt} \%)$, and distilled water. The LWR was 15 . In this study, four catalysts $\left(\mathrm{NH}_{4}\right)_{6} \mathrm{Mo}_{7} \mathrm{O}_{24}, \mathrm{MnSO}_{4}, \mathrm{TiO}_{2}$, and $\mathrm{H}_{2} \mathrm{SO}_{4}$ with the high delignification efficiency in a fraction of $1 \%$ of the wood weight were used. The delignification was performed at temperatures of $90^{\circ} \mathrm{C}$ and $100{ }^{\circ} \mathrm{C}$ for 3 and $4 \mathrm{~h}$ under constant stirring. After the completion of the delignification process, a fixed residue (the cellulosic product) was separated from the delignification liquids by filtration on a Büchner funnel, washing until neutral $\mathrm{pH}$, and drying to the air-dry state.

Liquor 1 (Figure 6) containing delignification liquids was concentrated on a rotary evaporator. Then, hot $\left(\sim 60^{\circ} \mathrm{C}\right)$ water was added in a volumetric ratio of 1:1 and driven off in a rotary evaporator. This procedure was performed twice to remove acetic acid. The HCs were precipitated with a fivefold volume of ethanol $(96 \mathrm{wt} \%)$ under slow stirring and then held at a temperature of $4{ }^{\circ} \mathrm{C}$ for $12 \mathrm{~h}$. The obtained white curdled HC precipitate was separated from the lignin depolymerization products (liquor 2 in Figure 6) by filtration on a Büchner funnel, washed with ethanol, frozen, and dried in an Iney- 6 freeze dryer.

The obtained HCs were analyzed by FTIR spectroscopy, GC, GPC, and TGA. The antioxidant activity was studied using compounds modeling free radicals: DPPH and hydroxyl radicals (ferrous sulfate $\mathrm{FeSO}_{4}$ ). The elemental composition was examined.

\subsection{Monosaccharide Composition of the Hemicelluloses}

To determine the monosaccharide composition, the HCs were hydrolyzed by a $2 \%$ $\mathrm{HCl}$ solution for $3 \mathrm{~h}$. The individual composition and monosaccharide content in the hydrolysates were determined on a VARIAN-450 GC gas chromatograph equipped with a flame ionization detector on a VF-624ms capillary column with a length of $30 \mathrm{~m}$ and an inner diameter of $0.32 \mathrm{~mm}$. The hydrolysate sample was pre-derivatized by the technique described in [44] with the formation of trimethylsilyl derivatives. The silylation reagent was a mixture of trimethylchlorosilane and hexamethyldisilazane in pyridine; sorbitol was used as an internal standard (IS). Standards for analyzing the hydrolysates were glucose, arabinose, galactose, sorbitol, mannose, and xylose (Panreac, Darmstadt, Germany).

\subsection{Gel Permeation Chromatography}

The weight average molar mass $\mathrm{M}_{\mathrm{w}}$, number average molar mass $\mathrm{M}_{\mathrm{n}}$, polydispersity index PDI, and K of the HC samples were determined by GPC using an Agilent 1260 Infinity II multi-detector GPC/SEC system with a refractive detector. The separation was made on two Agilent PL aquagel-OH columns using the solution of $0.1 \mathrm{M} \mathrm{LiNO}_{3}$ in water as a mobile phase. The column was calibrated using Agilent polyethylene glycol standards (US). The eluent flow rate was $1 \mathrm{~mL} / \mathrm{min}$ and the sample volume was $100 \mu \mathrm{L}$. Before the analysis, the samples were dissolved in the mobile phase $(\sim 5 \mathrm{mg} / \mathrm{mL})$ and filtered through a $0.45-\mu \mathrm{m}$ Agilent PES membrane filter (Millipore, Burlington, MA, USA). The data collection and processing were performed using the Agilent GPC/SEC MDS software.

\subsection{Fourier-Transform Infra-Red Spectroscopy Study}

The IR spectra were recorded on a Shimadzu IRTracer-100 FTIR spectrometer (Japan). Specimens for recording the IR absorption spectra were pressed in tablets containing $3 \mathrm{mg}$ of the sample in a potassium bromide matrix.

\subsection{Thermogravimetric Analysis}

The thermogravimetric analysis was made on a NETZSCH STA 449 F1 Jupiter simultaneous thermal analysis instrument (Selb, Germany). The HC samples were analyzed in argon at a heating rate of $10^{\circ} \mathrm{C} \cdot \mathrm{min}^{-1}$, temperatures from 30 to $900{ }^{\circ} \mathrm{C}$, and protective and blowout gas flow rates of 20 and $50 \mathrm{~mL} \cdot \mathrm{min}^{-1}$, respectively. The $\mathrm{Al}_{2} \mathrm{O}_{3}$ cylindrical crucible with a perforated cover was used and a reference was the empty corundum crucible with a cover. The instrument was calibrated according to the specification using reference sub- 
stances supplied with the instrument. The sample weight for the analysis was determined on a Sartorius BP121S analytical lab scale digital balance. The measurement data were processed using the NETZSCH. Proteus Thermal Analysis.5.1.0 software supplied with the instrument.

\subsection{Elemental Analysis}

The elemental analysis of the HCs isolated from the liquid products of the catalytic and noncatalytic delignification of spruce wood in the acetic acid-hydrogen peroxide-water medium was made on a Vario El Cube ELEMENTAR CHNSO analyzer (Hanau, Germany).

\subsection{Antioxidant Activity}

The absorption capacity of DPPH was used to establish the HC antioxidant activity determined by the method described in [45] with some modifications.

A solution of DPPH in ethanol $(0.2 \mathrm{mmol} / \mathrm{L})$ was prepared before the UV measurements. The HC samples were dissolved in distilled water at a concentration of 0.08 $2 \mathrm{mg} / \mathrm{mL}$. The polysaccharide solutions $(1 \mathrm{~mL})$ were thoroughly mixed with $2 \mathrm{~mL}$ of freshly prepared DPPH and $2 \mathrm{~mL}$ of ethanol. The mixtures were well-mixed and kept at room temperature for $30 \mathrm{~min}$ in the dark. After that, the absorbance was measured at $517 \mathrm{~nm}$ against a blank. The lower absorption of the reaction mixture indicates the higher free radical scavenging activity, as can be seen in the inhibition percent versus compound concentration plot. In this study, Vc was used as a positive control. The experiments were repeated three times and the obtained values were averaged.

The DPPH scavenging ability was calculated using the equation:

$$
\text { DPPH Radical Scavenging Ability }(\%)=\left(1-\frac{A_{S}-A_{B}}{A_{C}}\right) \times 100 \%
$$

where $A_{C}$ was the absorbance of the DPPH solution without a sample, $A_{S}$ was the absorbance of the test sample mixed with the DPPH solution, and $A_{B}$ was the absorbance of the sample without DPPH solution.

\section{Conclusions}

The oxidative catalytic and noncatalytic delignification of spruce wood in the acetic acid-water-hydrogen peroxide medium was studied. The investigated processes can be used to fractionate wood into two high-demand products: cellulose and hemicelluloses. The maximum hemicellulose yield (up to $10.9 \mathrm{wt} \%$ ) was attained with the $\left(\mathrm{NH}_{4}\right)_{6} \mathrm{Mo}_{7} \mathrm{O}_{24}$ and $\mathrm{MnSO}_{4}$ catalysts at a process temperature of $100{ }^{\circ} \mathrm{C}$.

The isolated hemicelluloses consist mainly of galactoglucomannan and some amount of arabinoglucuronoxylan and are free of residual lignin. It was found that the spruce hemicelluloses isolated in the presence of the $\left(\mathrm{NH}_{4}\right)_{6} \mathrm{Mo}_{7} \mathrm{O}_{24}, \mathrm{MnSO}_{4}$, and $\mathrm{TiO}_{2}$ catalysts have a narrow molecular weight distribution and a weight average molar mass of $\mathrm{M}_{\mathrm{W}}=16-42 \mathrm{~kg} / \mathrm{mol}$. The conformation and brunching of hemicellulose molecules are significantly affected by the process conditions and a catalyst used. The use of the water-soluble $\left(\mathrm{NH}_{4}\right)_{6} \mathrm{Mo}_{7} \mathrm{O}_{24}$ and $\mathrm{MnSO}_{4}$ catalysts leads to the partial depolymerization intensified with increasing temperature, which is reflected in the change in the conformation and branching of polysaccharides. When the heterogeneous $\mathrm{TiO}_{2}$ catalyst is used, the molecular weight distribution and polydispersity of the obtained hemicelluloses are comparable with the products of the noncatalytic process. Sulfuric acid significantly accelerates the acid hydrolysis of hemicelluloses; as a result, an inhomogeneous product in the form of a mixture of mono-, di-, and polysaccharides is obtained for only $2 \mathrm{~h}$.

The hemicelluloses isolated from spruce wood are resistant to heating to temperatures of up to $100{ }^{\circ} \mathrm{C}$; the most rapid weight loss is observed at $270-320^{\circ} \mathrm{C}$. The intense decomposition ends at $340{ }^{\circ} \mathrm{C}$ and $300{ }^{\circ} \mathrm{C}$ for the sample obtained with the $\mathrm{H}_{2} \mathrm{SO}_{4}$ catalyst.

The hemicelluloses extracted with the $\left(\mathrm{NH}_{4}\right)_{6} \mathrm{Mo}_{7} \mathrm{O}_{24}, \mathrm{MnSO}_{4}$, and $\mathrm{TiO}_{2}$ catalysts showed a fairly high antioxidant activity in the range of $5-44 \%$ at a concentration of 
0.08-2 mg/mL, except for the hemicelluloses obtained with the sulfuric acid catalyst, which exhibit the low antioxidant activity over the entire concentration range.

The obtained hemicelluloses can be used in biomedicine and the fabrication of multicomponent coatings and fillers for the food and pharmaceutical industries.

Author Contributions: Conceptualization, V.S.B., Y.N.M. and I.G.S.; methodology, Y.N.M., I.G.S. and A.I.C.; software, V.S.B., Y.N.M. and N.I.; validation, V.S.B., Y.N.M. and I.G.S.; formal analysis, V.S.B., A.V.M., A.M.S., E.D.S., O.Y.F.; investigation, D.V.Z., V.A.I., A.A.S.; resources, Y.N.M. and I.G.S.; data curation, V.S.B. and A.I.C.; writing-original draft preparation, V.S.B., Y.N.M. and A.I.C.; writing-review and editing, V.S.B., Y.N.M., A.S.K.; visualization, V.S.B., Y.N.M., N.I.; supervision, Y.N.M. and I.G.S.; project administration, Y.N.M.; funding acquisition, Y.N.M. All authors have read and agreed to the published version of the manuscript.

Funding: The research was funded by RFBR, Krasnoyarsk Territory and Krasnoyarsk Regional Fund of Science, project number 20-43-242906. This study was carried out within the budget project \#0287-2021-0012 for the Institute of Chemistry and Chemical Technology, Siberian Branch of the Russian Academy of Sciences.

Data Availability Statement: All the data generated during this study are included in this article.

Acknowledgments: This study was carried out using the equipment of the Krasnoyarsk Regional Centre for Collective Use, Krasnoyarsk Scientific Center, Siberian Branch of the Russian Academy of Sciences.

Conflicts of Interest: The authors declare no conflict of interest.

Sample Availability: Samples of the compounds are available from the authors.

\section{References}

1. Chudina, A.I.; Malyar, Y.N.; Sudakova, I.G.; Kazachenko, A.S.; Skripnikov, A.M.; Borovkova, V.S.; Kondrasenko, A.A.; Mazurova, E.V.; Fetisova, O.Y.; Ivanov, I.P. Physicochemical characteristics of polysaccharides from catalytic and noncatalytic acetic acidperoxide delignification of larch wood. Biomass Conv. Bioref. 2021. [CrossRef]

2. Willför, S.; Sundberg, K.; Tenkanen, M.; Holmbom, B. Spruce-derived mannans-A potential raw material for hydrocolloids and novel advanced natural materials. Carbohydr. Polym. 2008, 72, 197-210. [CrossRef]

3. Várnai, A.; Siika-aho, M.; Viikari, L. Restriction of the enzymatic hydrolysis of steam-pretreated spruce by lignin and hemicellulose. Enzym. Microb. Technol. 2010, 46, 185-193. [CrossRef]

4. Sun, X.-F.; Wang, H.; Jing, Z.; Mohanathas, R. Hemicellulose-based pH-sensitive and biodegradable hydrogel for controlled drug delivery. Carbohydr. Polym. 2013, 92, 1357-1366. [CrossRef] [PubMed]

5. Deloule, V.; Boisset, C.; Hannani, D.; Suau, A.; Gouellec, A.; Chroboczek, J.; Botté, C.; Yamaryo-Botté, Y.; Chirat, C.; Toussaint, B. Prebiotic role of softwood hemicellulose in healthy mice model. J. Funct. Foods 2020, 64, 103688. [CrossRef]

6. Mendes, F.R.S.; Bastos, M.S.R.; Mendes, L.G.; Silva, A.R.A.; Sousa, F.D.; Monteiro-Moreira, A.C.O.; Cheng, H.N.; Biswas, A.; Moreira, R.A. Preparation and evaluation of hemicellulose films and their blends. Food Hydrocoll. 2017, 70, 181-190. [CrossRef]

7. Xu, W.; Pranovich, A.; Uppstu, P.; Wang, X.; Kronlund, D.; Hemming, J.; Öblom, H.; Moritz, N.; Preis, M.; Sandler, N.; et al. Novel biorenewable composite of wood polysaccharide and polylactic acid for three dimensional printing. Carbohydr. Polym. 2018, 187, 51-58. [CrossRef]

8. Gautam, D.; Kumari, S.; Ram, B.; Chauhan, G.S.; Chauhan, K. A new hemicellulose-based adsorbent for malachite green. J. Environ. Chem. Eng. 2018, 6, 3889-3897. [CrossRef]

9. Mikkonen, K.S.; Kirjoranta, S.; Xu, C.; Hemming, J.; Pranovich, A.; Bhattarai, M.; Peltonen, L.; Kilpeläinen, P.; Maina, N.; Tenkanen, M.; et al. Environmentally-compatible alkyd paints stabilized by wood hemicelluloses. Ind. Crop. Prod. 2019, 133, 212-220. [CrossRef]

10. Krogell, J.; Korotkova, E.; Eränen, K.; Pranovich, A.; Salmi, T.; Murzin, D.; Willför, S. Intensification of hemicellulose hot-water extraction from spruce wood in a batch extractor-Effects of wood particle size. Bioresour. Technol. 2013, 143, 212-220. [CrossRef] [PubMed]

11. Song, T.; Pranovich, A.; Holmbom, B. Effects of $\mathrm{pH}$ control with phthalate buffers on hot-water extraction of hemicelluloses from spruce wood. Bioresour. Technol. 2011, 102, 10518-10523. [CrossRef]

12. Gallina, G.; Cabeza, Á.; Grénman, H.; Biasi, P.; García-Serna, J.; Salmi, T. Hemicellulose extraction by hot pressurized water pretreatment at $160^{\circ} \mathrm{C}$ for 10 different woods: Yield and molecular weight. J. Supercrit. Fluids 2018, 133, 716-725. [CrossRef]

13. Alvarez-Vasco, C.; Zhang, X. Alkaline hydrogen peroxide pretreatment of softwood: Hemicellulose degradation pathways. Bioresour. Technol. 2013, 150, 321-327. [CrossRef] [PubMed]

14. Chadni, M.; Bals OZiegler-Devin, I.; Brosse, N.; Grimi, N. Microwave-assisted extraction of high-molecular-weight hemicelluloses from spruce wood. Comptes Rendus Chim. 2019, 22, 574-584. [CrossRef] 
15. Oh, M.H.; Yoon, K.Y. Comparison of the Biological Activity of Crude Polysaccharide Fractions Obtained from Cedrela sinensis Using Different Extraction Methods. Pol. J. Food Nutr. Sci. 2018, 68, 327-334. [CrossRef]

16. Chadni, M.; Grimi, N.; Bals, O.; Ziegler-Devin, I.; Brosse, N. Steam explosion process for the selective extraction of hemicelluloses polymers from spruce sawdust. Ind. Crop. Prod. 2019, 141, 111-757. [CrossRef]

17. Kazachenko, A.S.; Malyar, Y.N.; Vasilyeva, N.Y.; Fetisova, O.Y.; Chudina, A.I.; Sudakova, I.G.; Antonov, A.V.; Borovkova, V.S.; Kuznetsova, S.A. Isolation and sulfation of galactoglucomannan from larch wood (Larix sibirica). Wood Sci. Technol. 2021, 55, 1091-1107. [CrossRef]

18. Kuznetsov, B.N.; Chesnokov, N.V.; Sudakova, I.G.; Garyntseva, N.V.; Kuznetsova, S.A.; Malyar, Y.u.N.; Yakovlev, V.A.; Djakovitch, L. Green catalytic processing of native and organosolv lignins. Catal. Today 2018, 309, 18-30. [CrossRef]

19. Kuznetsov, B.N.; Sudakova, I.G.; Yatsenkova, O.V.; Garyntseva, N.V.; Rataboul, F.; Djakovitch, L. Optimizing Single-Stage Processes of Microcrystalline Cellulose Production via the Peroxide Delignification of Wood in the Presence of a Titania Catalyst Catal. Ind. 2018, 10, 360-367. [CrossRef]

20. Bragatto, J.; Segato, F.; Squina, F.M. Production of xylooligosaccharides (XOS) from delignified sugarcane bagasse by peroxideHAc process using recombinant xylanase from Bacillus subtilis. Ind. Crop. Prod. 2013, 51, 123-129. [CrossRef]

21. Wen, P.; Zhang, T.; Wang, J.; Lian, Z.; Zhang, J. Production of xylooligosaccharides and monosaccharides from poplar by a two-step acetic acid and peroxide/acetic acid pretreatment. Biotechnol. Biofuels 2019, 12, 1-13. [CrossRef]

22. Vila, C.; Santos, V.; Parajó, J.C. Simulation of an Organosolv Pulping Process: Generalized Material Balances and Design Calculations. Ind. Eng. Chem. Res. 2003, 42, 349-356. [CrossRef]

23. Suchy, M.; Argyropoulos, D.S. Catalysis and activation of oxygen and peroxide delignification of chemical pulps: A review. Tappi J. 2002,1,1-18.

24. Ma, R.; Xu, Y.; Zhang, X. Catalytic Oxidation of Biorefinery Lignin to Value-added Chemicals to Support Sustainable Biofuel Production. ChemSusChem. 2014, 8, 24-51. [CrossRef] [PubMed]

25. Xie, J.-H.; Zhang, F.; Wang, Z.-J.; Shen, M.-Y.; Nie, S.-P.; Xie, M.-Y. Preparation, characterization and antioxidant activities of acetylated polysaccharides from Cyclocarya paliurus leaves. Carbohydr. Polym. 2015, 133, 596-604. [CrossRef]

26. Cui, H.-Y.; Wang, C.-L.; Wang, Y.-R.; Li, Z.-J.; Zhang, Y.-N. The polysaccharide isolated from Pleurotus nebrodensis (PN-S) shows immune-stimulating activity in RAW264.7 macrophages. Chin. J. Nat. Med. 2015, 13, 355-360. [CrossRef]

27. Jia, X.; Zhang, C.; Qiu, J.; Wang, L.; Bao, J.; Wang, K.; Zhang, Y.; Chen, M.; Wan, J.; Su, H.; et al. Purification, structural characterization and anticancer activity of the novel polysaccharides from Rhynchosia minima root. Carbohydr. Polym. 2015, 132, 67-71. [CrossRef]

28. Fyhrquist, P.; Virjamo, V.; Hiltunen, E.; Julkunen-Tiitto, R. Epidihydropinidine, the main piperidine alkaloid compound of Norway spruce (Picea abies) shows promising antibacterial and anti-Candida activity. Fitoterapia 2017, 117, 138-146. [CrossRef]

29. Normand, M.L.; Mélida, H.; Holmbom, B.; Michaelsen, T.E.; Inngjerdingen, M.; Bulone, V.; Paulsen, B.S.; Ek, M. Hot-water extracts from the inner bark of Norway spruce with immunomodulating activities. Carbohydr. Polym. 2014, 101, 699-704. [CrossRef] [PubMed]

30. Neupane, S.; Bittkau, K.S.; Alban, S. Size distribution and chain conformation of six different fucoidans using size-exclusion chromatography with multiple detection. J. Chromatogr. A 2020, 1612, 460658. [CrossRef]

31. Anca-Couce, A.; Obernberger, I. Application of a detailed biomass pyrolysis kinetic scheme to hardwood and softwood torrefaction. Fuel 2016, 167, 158-167. [CrossRef]

32. Hu, T.T.; Liu, D.; Chen YWu, J.; Wang, S.S. Antioxidant activity of sulfatedpolysaccharide fractions extracted from Undaria pinnitafida in vitro. Int. J. Biol. Macromol. 2010, 46, 193-198. [CrossRef]

33. Dumore, N.S.; Mukhopadhyay, M. Antioxidant properties of aqueous selenium nanoparticles (ASeNPs) and its catalysts activity for 1, 1-diphenyl-2-picrylhydrazyl (DPPH) reduction. J. Mol. Struct. 2020, 1205, 127637. [CrossRef]

34. Hara, K.; Someya, T.; Sano, K.; Sagane, Y.; Watanabe, T.; Wijesekara, R.G.S. Antioxidant activities of traditional plants in Sri Lanka by DPPH free radical-scavenging assay. Data Brief. 2018, 17, 870-875. [CrossRef]

35. Fadda, A.; Serra, M.; Molinu, M.G.; Azara, E.; Barberis, A.; Sanna, D. Reaction time and DPPH concentration influence antioxidant activity and kinetic parameters of bioactive molecules and plant extracts in the reaction with the DPPH radical. J. Food Compos. Anal. 2014, 35, 112-119. [CrossRef]

36. Ji, X.; Liu, F.; Ullah, N.; Wang, M. Isolation, purification, and antioxidant activities of polysaccharides from Ziziphus Jujuba cv. Muzao. Int. J. Food Prop. 2018, 21, 1-11. [CrossRef]

37. Abdelhalim, A.O.E.; Meshcheriakov, A.A.; Maistrenko, D.N.; Molchanov, O.E.; Ageev, S.V.; Ivanov, D.A.; Iamalov, N.R.; Luttsev, M.D.; Vasina, L.V.; Sharoyko, V.V.; et al. Graphene oxide enriched with oxygen-containing groups: On the way to an increase of antioxidant activity and biocompatibility. Colloids Surf. B Biointerfaces 2021, 112232. [CrossRef] [PubMed]

38. Ahmad, M.M. Characterization and antioxidant activities of polysaccharides extracted from flageolet bean pods waste. Curr. Res. Green Sustain. Chem. 2021, 4, 100154. [CrossRef]

39. Yi, J.; Li, X.; Wang, S.; Wu, T.; Liu, P. Steam explosion pretreatment of Achyranthis bidentatae radix: Modified polysaccharide and its antioxidant activities. Food Chem. 2021, 375, 131746. [CrossRef] [PubMed]

40. Rivas, S.; Enma, S.R.; Moure, C.A.; Juan, H.D.; Parajó, C. Characterization, refining and antioxidant activity of saccharides derived from hemicelluloses of wood and rice husks. Food Chem. 2013, 141, 495-502. [CrossRef] 
41. Bogdanović, J.; Mitrović, P.A.; Spasojević, I. A comparative study of antioxidative activities of cell-wall polysaccharides. Carbohydr. Res. 2011, 346, 2255-2259.

42. Ebringerová, A.; Hromádková, Z.; Hř́ibalová, V.; Xu, C.; Holmbom, B.; Sundberg, A.; Willför, S. Norway spruce galactoglucomannans exhibiting immunomodulating and radical-scavenging activities. Int. J. Biol. Macromol. 2008, 42, 1-5. [CrossRef] [PubMed]

43. Sjöström, E.; Alén, R. Analytical Methods of Wood Chemistry, Pulping, and Papermaking; Springer: Berlin/Heidelberg, Germany, 1999.

44. Ruiz-Matute, A.I.; Hernández-Hernández, O.; Rodríguez-Sánchez, S.; Sanz, M.L.; Martínez-Castro, I. Derivatization of carbohydrates for GC and GC-MS analyses. J. Chromatogr. B 2011, 879, 1226-1240. [CrossRef] [PubMed]

45. Xua, Y.; Songa, S.; Weia, Y.; Wangb, F.; Zhaoa, M.; Guoa, J.; Zhanga, J. Sulfated modification of the polysaccharide from Sphallerocarpusgracilis and its antioxidant activities. Int. J. Biol. Macromol. 2016, 87, 180-190. [CrossRef] [PubMed] 